DOI: $10.2478 / \mathrm{v} 10025-010-0001-1$

JOURNAL OF WATER

AND LAND DEVELOPMENT

J. Water Land Dev. No. 13b, 2009: 3-16

\title{
Water for agriculture and natural environment
}

\section{Waldemar MIODUSZEWSKI}

Institute for Land Reclamation and Grassland Farming, Department of Water Resources, Falenty, ul. Hrabska 3, 05-090 Raszyn, Poland, e-mail: w.mioduszewski@imuz.edu.pl

\begin{abstract}
Views on the objectives and role of water management have remarkably changed in the last years. The need of a complex water management that would consider all water users including agriculture and natural environment is often underlined. It is pointed out that agriculture and natural environment (including commercial forests) are basic consumers of precipitation water which is not considered in water and economic balances. More and more importance is attributed to the utilisation of waters from catchment basin and to application of non-technical measures of controlling water cycles. A large impact of agro-ecosystems and natural or semi-natural (forests, wetlands) ecosystems on water balance is underlined. This different approach to the problems of water management is expressed e.g. in Water Framework Directive of European Union devoted to surface and ground water protection. The directive attributes a great role to the protection of aquatic and water related ecosystems. More and more often it is realised that the total water resources are equal to the volume of atmospheric precipitation. Water management should involve not only the water in geological aquifers or river channels but also that which is retained in soil profile. Such elements of water balance as spatial distribution, interception, infiltration and recharge of ground water reservoirs, soil retention capacity, surface runoff and evapotranspiration depend largely on land use in a catchment. Through appropriate land use and catchment management, application of rational agro-technical methods, development of small retention, wetland restoration, and hampering water outflow from draining systems one may significantly affect water cycling in a catchment.

Small water resources of Poland, increasing water consumption, climate changes and requirements of environmental protection enforce the implementation of complex methods of water management and search for environmental-friendly methods of limiting economic losses caused by water deficit or excess. Saving water used for economic purposes and agriculture would permit better fulfilment of the needs of natural environment.
\end{abstract}

Key words: agriculture, environment, hydrology, water management, water resources

\section{INTRODUCTION}

Significant changes in views on the role of water management particularly in rural areas have taken place in recent years. More importance is attached to the use of own catchment's waters and to the application of non-technical methods in regulating water cycles. The significance of agro-ecosystems and natural or close to 
natural ecosystems (forests, wetlands) in water balance is being underlined (Dyrektywa..., 2000; KęDZIORA, 2006; MIODUSZEWSKI, 1999; Rezolucja..., 2008). Water Framework Directive (WFD) of the European Union (Dyrektywa..., 2000) attaches great importance to the protection of aquatic and water related ecosystems. Similarly formulated are the aims of water management in the National Strategy of Water Management (Narodowa..., 2008). Both documents focus on the management of surface and ground waters as the basic water resources. It is, however, more and more often emphasized (DROOGERS and IMMERZEEL, 2008; RIJSBERMAN, 2006; SHARMA, 2006) that the total water resource for water balance equals the volume of atmospheric precipitation. Water management should consider not only part of water stored in aquifers and river channels but also that which is retained in soil profiles (Implementation..., 2008; LAWRANCE et al., 2002, RIJSBERMAN, 2006) and constitutes the main water resource for plants. It means that we should analize the distribution at precipitation as total water resources among different users, including nature.

Characteristic feature of contemporary planning of water management is the assumption that human activity is an element of hydrologic cycle and as such could not be neglected. Such elements of water balance as spatial distribution of interception, infiltration and ground water recharge, soil retention capacity, surface runoff, and evapotranspiration depend largely on land use, and human activity.

Atmospheric precipitations are the basic source of water resources. Hence, evapotranspiration being the difference between precipitation and outflow may be dealt with as water intake for biomass production. Agricultural crops, forest ecosystems, natural vegetation are the main water consumers. Plant demands for water should not be passed over in balancing waters. A possibility of regulating evapotranspiration in the catchment area is more and more often considered in countries of small water resources (DROOGERS and IMMERZEEL, 2008; RIJSBERMAN, 2006).

The distribution of precipitation in a catchment basin and fulfilment of the needs of various users depends largely on potential retention (storage) capacity (BYCZKOWSKI, 2003; KĘDZIORA, 2006). Natural potential retention capacity of river watersheds has been decreased in many areas by anthropogenic factors. Accelerated water cycle and transport of matter in catchments unfavourably altered the structure of water balance and was the main source of increased nitrogen loads delivered to rivers from croplands (HOFFMAN et al., 2000). It seems rational to undertake actions in order to increase (reconstruct) the retention capacity of river watersheds. On the other hand, it is necessary to use available resources of both surface and ground waters and those retained in soil profiles more efficiently (economically) (BROWN, 2002; DroOgERS and IMMERZEEL, 2008; Human..., 2006; Implementation..., 2008).

This paper was intended to present water availability in rural areas and to analyse the possibility of fulfilment the needs of agriculture (crops) and natural envi- 
ronment as the main water consumers. The experiences show that nowadays more water for rained or irrigated agriculture very often means less water for environment (MIODUSZEWSKI, 2008; RIJSBERMAN, 2006; RIMENTAL, 2006). Sometimes it is difficult to keep minimum flow in the river, necessary for preserving nature, if water is taken for irrigation.

\section{INDICATORS OF WATER RESOURCES}

Many authors (BYCZKOWSKI, 2003; MIODUSZEWSKI, 2008; Narodowa..., 2008) underlined that Poland is situated in a specific climatic zone of low precipitation and relatively high evapotranspiration. Therefore, water resources of Poland are smaller than those of neighbour countries. There are many indices to assess water resources in the global scale and to compare water richness of various countries (FALKENMARK and LANNERSTAD, 2005; Indicator... 2009; MIODUSZEWSKI, 2008; RIJSBERMAN, 2006).

Surface water resources index. The per capita volume of surface waters (of the sum of annual river outflow) (FALKENMARK, 2005) describes "the access to surface waters". Surface water resources below $1000 \mathrm{~m}^{3} \cdot$ person $^{-1} \cdot \mathrm{year}^{-1}$ are considered extremely low and countries having such resources face chronic water deficits. Very small resources are those between 1000 and $2000 \mathrm{~m}^{3} \cdot$ person $^{-1} \cdot$ year $^{-1}$. Only the countries having more than $5000 \mathrm{~m}^{3} \cdot$ person $^{-1} \cdot \mathrm{year}^{-1}$ per capita might be considered as such of moderate water resources.

The index is often subject to critique since it doesn't account for temporal (annual) and spatial variability of water resources, climatic conditions, actual water demands, economic development etc.

Water exploitation index (water intake). To assess current status of water resources the index is proposed which would be defined as the ratio of the total water intake to the total surface and ground water resources in the yearly scale (LALLANA and MARCUELLO, 2004). The index is expressed in percent.

Water poverty index. The index (Indicator..., 2009; LAWRANCE, 2002; Using..., 2008) is estimated based on the analysis of many parameters like: water resources status (the amount of water and its quality), availability (distance from sources, time of acquisition), skills (possibility of paying the costs of purification, the ways of water management), utilisation (methods of water utilisation) and environmental conditions (ecosystem status, erosion).

Values of these indices calculated for European countries are presented in Fig. 1. Water poverty index and surface water resources index are very unfavourable for Poland. Acc, to these indices Poland is the country extremely poor in water. Slightly better situation is indicated by the index of water exploitation (intake). Acc. to this index countries poor in water take up more than $40 \%$ of their total water resources. In Poland this index was $37 \%$ in 1990 and now it is lower than $20 \%$. 


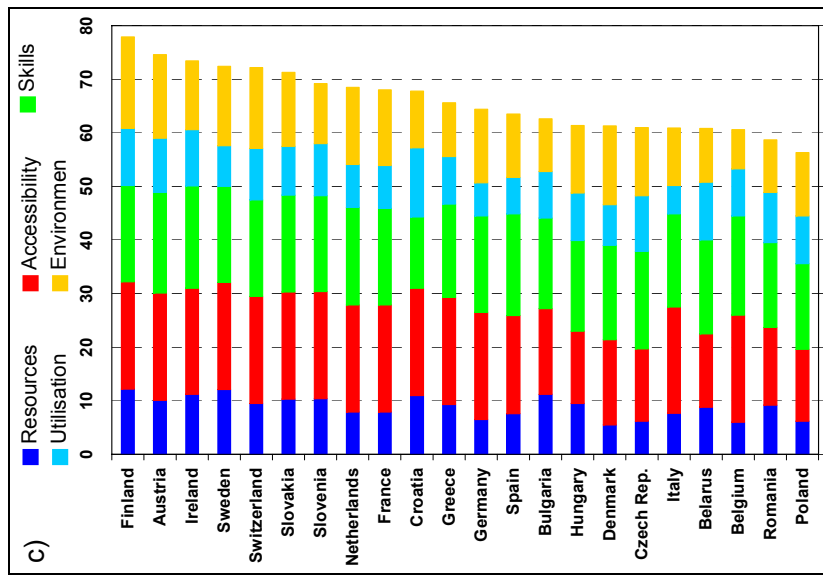

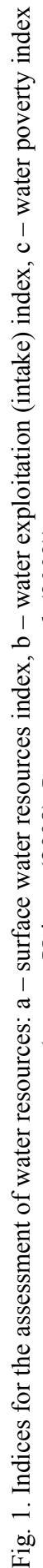
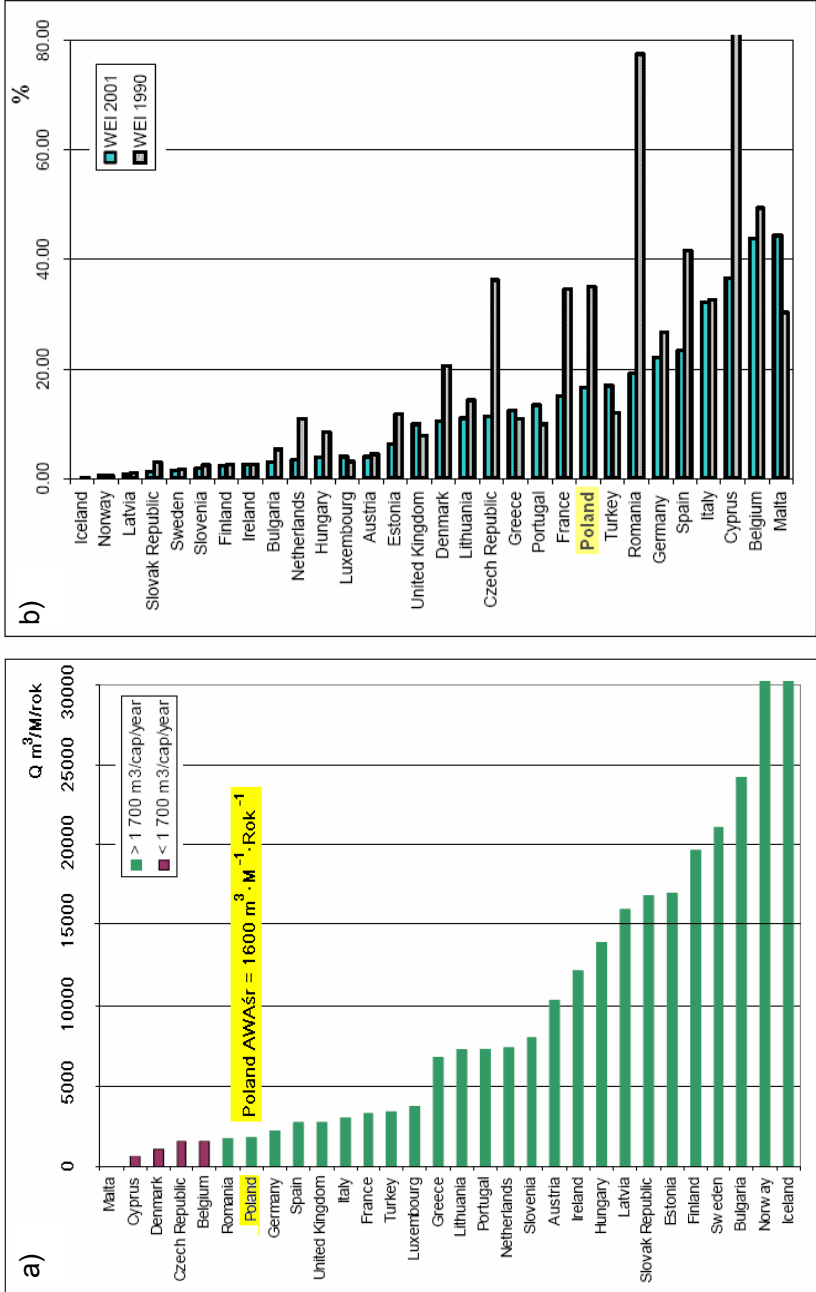
Substantial decrease of water consumption for economic purposes and in agriculture (irrigation) has taken place recently.

Small water resources in Poland are the result of lower precipitation and higher evapotranspiration as compared with neighbours and with other European countries. On the other hand, there are periods in Poland of "water excess" manifesting itself by floods and excessive soil moisture. Therefore, large drainage projects were implemented in arable lands and channels and draining ditches were built to intensify the use of meadows and pastures.

\section{THE PRINCIPLE OF WATER BALANCE}

Simplified annual water balance for a long time period may be calculated as:

$$
P=Q+H
$$

where:

$P \quad=192.4$ billion $\mathrm{m}^{3}$ (precipitation),

$Q=58.6$ billion $\mathrm{m}^{3}$ (river outflow - blue water),

$H=133.8$ billion $\mathrm{m}^{3}$ (evapotranspiration, evaporation from water surface etc. - green water).

$H$ component of the balance was being called very often as „losses” in hydrology (BYCZKOWSKI, 2003) since it is part of atmospheric precipitation which not reach rivers and therefore can not be taken up for municipal or industrial purposes.

Balancing water in a catchment basin for planning purposes involves comparison of total resources of surface and ground waters with total water intake by various users. It does not consider water resources retained in soils and that part of water which is taken up by plants (evapotranspiration).

The new idea of water management is taking in the consideration the precipitation as a total water resources which is devided for blue and green water. Waters flowing in a river (Fig. 2) are usually named blue waters while those used by plants - green waters (CHAPAGAIN and HOEKSTRA, 2004; HOEKSTRA and CHAPAGAIN, 2007; RENAULT, 2003). The blue water which is used by different users and return to rivers is called grey water. This definition allows better understanding of the water management idea. According to the data of the Polish Main Statistical Office (GUS) (Ochrona..., 2006) the total uptake of blue waters for economic purposes is c. 12 billion $\mathrm{m}^{3}$. Waters taken up for industrial and municipal needs after their use are delivered to rivers as more or less treated waste waters. This part of water is named - grey water. Water taken up by crops, forests and natural vegetation are mostly used in the process of evapotranspiration and turned into water vapour. Table 1 shows estimates of total water intakes and the volume of irreversible consum- 


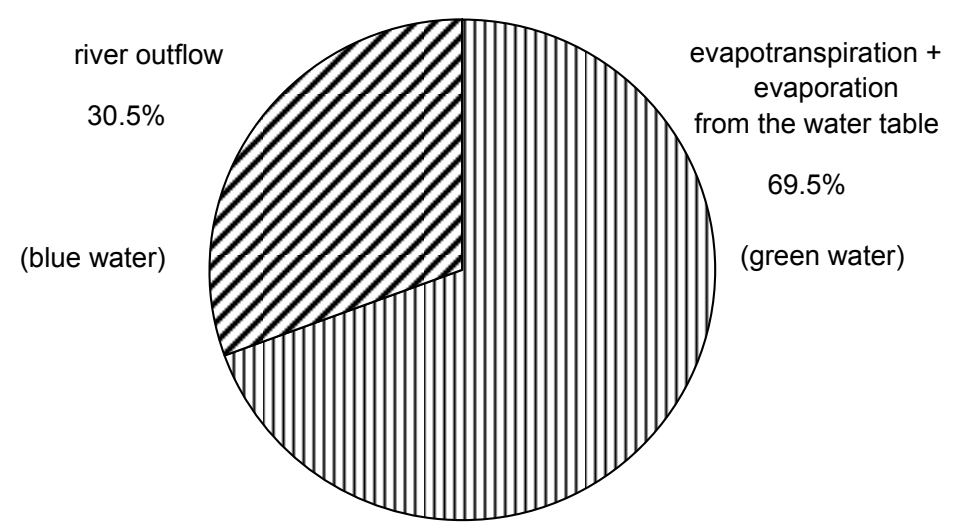

Fig. 2. Water balance of Poland

Table 1. Water intake for the needs of national economy $\left(\mathrm{km}^{3}\right)$ acc. to GUS (2006)

\begin{tabular}{|c|c|c|}
\hline Item & Total water intake acc. to GUS & $\begin{array}{c}\text { Estimated irreversible } \\
\text { consumption }\end{array}$ \\
\hline Production purposes (industry) & 8.5 & 0.8 \\
\hline Irrigation & 0.3 & 0.3 \\
\hline Fishponds & 0.8 & 0.2 \\
\hline Municipal water supply systems & 2.1 & 0.4 \\
\hline Total & 11.7 & 1.7 \\
\hline Grey water (sewage) & \multicolumn{2}{|c|}{$10.0 \mathrm{~km}^{3}$} \\
\hline
\end{tabular}

ption. Blue water taken up for various economic purposes (Tab. 1) constitutes $20 \%$ of the total river outflow. Irreversible consumption is only c. $3 \%$ of surface water resources.

Considering the amount of evapotranspiration and the type of land use, the intake of green water may be approximately divided into (MIODUSZEWSKI, 2008):

- agricultural lands $\quad 65.0$ billion $\mathrm{m}^{3}$

- forests

50.0 billion $\mathrm{m}^{3}$

- other

18.8 billion $\mathrm{m}^{3}$

Main consumers of green water are agriculture, forests and natural environment. Figure 3 presents schematic distribution of atmospheric precipitation (dealt with as the entire water resource) among particular types of water and various users.

Volumes of water used for economic purposes are relatively small in relation to water needed by plants. It is estimated that decreasing evapotranspiration by $1 \%$ worldwide would allow saving 24 litres of water per capita daily. Savings achieved through decreasing evapotranspiration by $10 \%$ would cover all human demands for water (both drinking and industrial). 


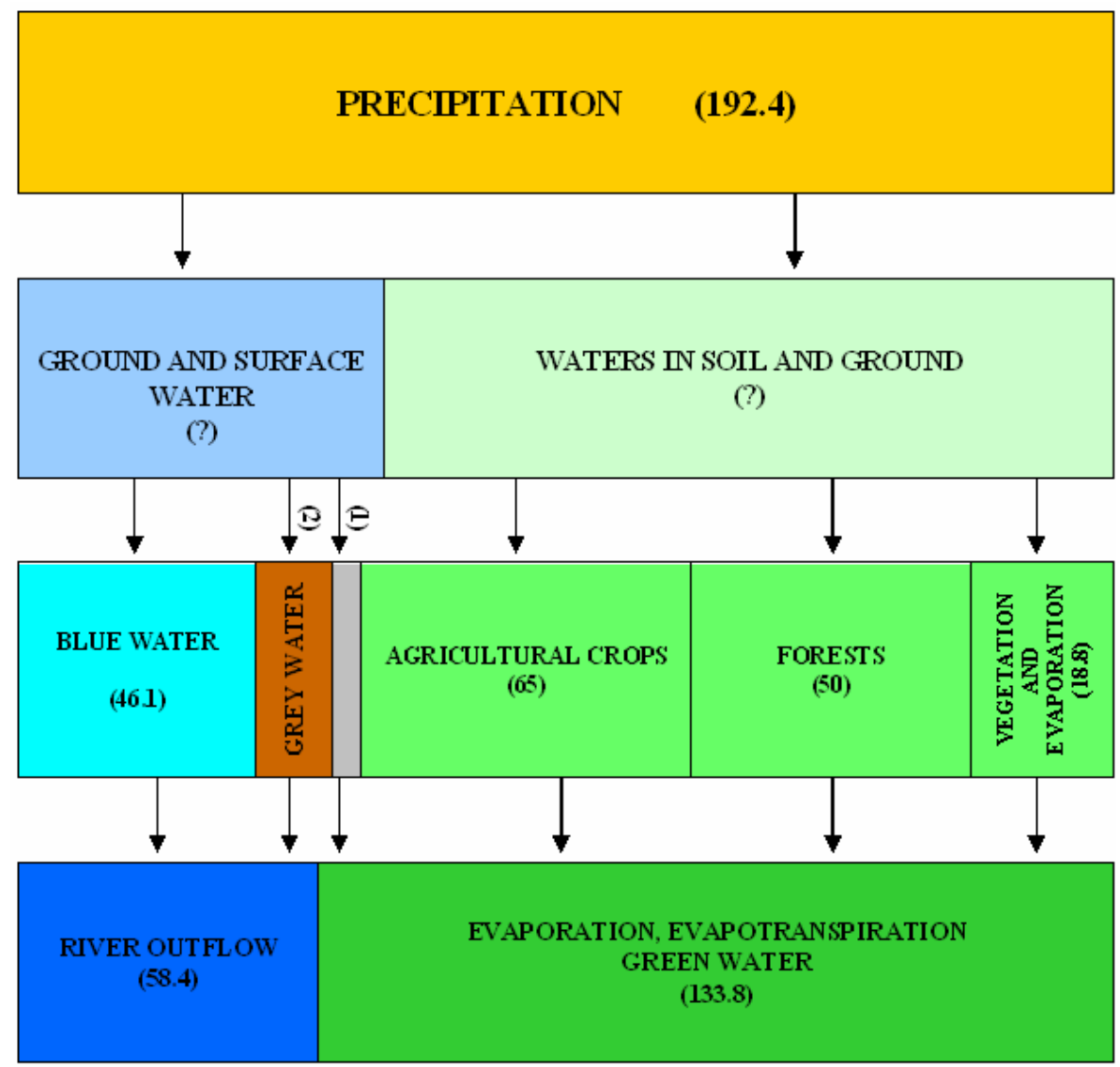

Fig. 3. Schematic diagramme of the distribution of precipitation; (1) irreversible losses $=1.7 \mathrm{~km}^{3}$, (2) waste waters $=10.0 \mathrm{~km}^{3},(1)+(2)=$ intake of blue water for economic purposes

According to most specialists (BROWN, 2002; Implementation..., 2008; PIMENTEL et al., 2006, SHIKLOMANOV, 1993) "the amount of water on Earth is sufficient to cover the household needs of people and the needs of industry and agriculture; the problem is in its distribution. It happens so, that water deficit is felt only by the poor" (Human..., 2006). But many authors (BROWN, 2002; NiTZSCHE et al., 2001; PiMENTEL et al., 2006; RIJSBERMAN, 2006; SHARMA, 2006) also notice that there is a justified fear of future occurrence of water deficit in food production. It was underlined at the Kyoto conference devoted to world problems of water in rural areas that if one should fear global crisis in water management, it will concern the lack of water for agriculture (MIODUSZEWSKI, 2004). In fact, more and more water in the world is taken up for irrigation. Competition for the access to water is being observed among various users including the demands of natural environment. In Poland because of rather poor agriculture and low yield of most plants in 
compare to the West Europe, the competition between agriculture and nature is not seen yet. But in some parts of Poland when agriculture is more intensive the problem of water is arising.

\section{DEMANDS FOR WATER}

Basic demand for water calculated per capita per day is estimated at (RENAULT, 2002):

- for drinking water 2-31·person ${ }^{-1} \cdot$ day $^{-1}$,

- for water for household purposes 30 (Ethiopia) - 400 (USA) $1 \cdot$ person $^{-1} \cdot$ day $^{-1}$,

- for food production 1500 (vegetarian diet) - 4000 (meat diet) $1 \cdot$ person $^{-1} \cdot$ day $^{-1}$.

Food production is very water-consuming. Approximate water demands for the production of selected food products are given in Table 2 .

Table 2. Water consumption for the production of selected food items (CHAPAGAin, HoEkstra, 2004)

\begin{tabular}{l|c|c}
\hline \multicolumn{1}{c|}{ Item } & Unit & Water volume \\
\hline 1 kg of wheat & litter & 800 \\
1 kg of maize & litter & 900 \\
1 cup $(125 \mathrm{ml})$ of coffee & litter & 140 \\
1 glass $(250 \mathrm{ml})$ of milk & litter & 200 \\
1 glass $(250 \mathrm{ml})$ of beer & litter & 75 \\
1 potato $(100 \mathrm{~g})$ & litter & 25 \\
1 kg of beef & litter & 16000 \\
1 hamburger $(150 \mathrm{~g})$ & litter & 2400 \\
$1 \mathrm{~m}^{3}$ of timber ${ }^{1)}$ & $\mathrm{m}^{3}$ & 1600 \\
1 litre of bio-fuel & $\mathrm{m}^{3}$ & 200 \\
\hline
\end{tabular}

${ }^{1)}$ Own study.

Energetic plants consume much water, hence the production of energy from biomass requires large water intake. Table 3 presents examples of water use for the production of 1 GJ energy with conventional methods and from renewable resources.

Table 4 shows approximate volumes of water necessary to produce some goods in the country. Population was assumed at 40 million people and calorific value of their daily diet - at $3000 \mathrm{kcal}$ per person. It was unrealistically assumed that the whole energetic needs of the country will be covered by biomass production. The set of data presented in Table 4 indicates that almost $100 \%$ of water now transpired by forests and crops would be needed to produce energy entirely from biomass. The other problem did not discussed here is the big area needed for bio- 
Table 3. Water consumption for energy production (from data given in GERBENS-LEENES et al. (2009))

\begin{tabular}{l|c}
\hline \multicolumn{1}{c|}{ Item } & $\begin{array}{c}\text { Water consumption } \\
\mathrm{m}^{3} \cdot \mathrm{GJ}^{-1}\end{array}$ \\
\hline Conventional methods & \\
$\quad$ - fuel oil & 1.1 \\
- coal & 0.2 \\
- natural gas & 0.1 \\
Renewable resources & \\
- solar energy & 0.3 \\
- wind energy & 0.0 \\
Biomass & \\
- maize and wheat & 9.0 \\
- sunflower & 27.0 \\
- miscanthus (Chinese reed) & 20.0 \\
- poplar (willow) & 22.0 \\
\hline
\end{tabular}

Table 4. Potential water demands to fulfil man's requirements

\begin{tabular}{lcc}
\hline \multicolumn{1}{c|}{ Item } & $\begin{array}{r}\text { Unit consumption } \\
\mathrm{m}^{3} \cdot \text { person }^{-1} \cdot \text { year }^{-1}\end{array}$ & $\begin{array}{c}\text { Needs in the whole country } \\
\text { billion } \mathrm{m}^{3}\end{array}$ \\
\hline $\begin{array}{l}\text { Food production (3000 kcal per capita daily) } \\
\text { Energy production (assuming 100 GJ.person }{ }^{-1} \text {. }\end{array}$ & 1300 & 52.0 \\
year $^{-1}$ ) & 35 & 1.4 \\
$\quad-$ conventional sources & 2420 & 96.8 \\
$\quad-$ biomass & 1 & 0.04 \\
Consumption of drinking water & 110 & 4.4 \\
Intake of household and industrial waters & & \\
\hline
\end{tabular}

mass production. Anyway the table shows that it is not enough water for energy from biomass.

Water intake for household purposes is expected to increase with economic development (increased hygienic standards) and increasing human population. The main increase of water use will, however, take place in agriculture. The improvement of food quality and increasing share of meat products in the diet will enlarge the water volume needed to produce food for one person. Noteworthy, this pessimistic prediction must not come true. Analyses made for 15 member countries of the European Union showed that the use of water necessary for per capita food production has decreased during the last 30 years (RENAULT, 2002). It is partly the result of changing dietary habits (less meat consumed). However, the decisive factor in decreasing water consumption is biological progress in agriculture. Much 
less water is used to produce $1 \mathrm{~kg}$ of corn now than it was years ago (HOEKSTRA and Chapagain, 2007; NitzSCHE et al., 2001; PiMENTEL et al., 2006).

Forest ecosystems and natural environment are, apart from agriculture, the main users of green (transpired) waters. Forests and wetlands have undoubtedly positive effect on water cycling in the catchment basin. One should, however, remember that both forests and natural vegetation need much water. Restoration of wetlands through increasing ground water table may enlarge evapotranspiration which in turn may reflect in decreased river water flows in vegetation periods. Afforestation may also limit water inflow to ground water aquifers.

Predictions of global climate changes suggest that one should expect in Poland larger and more violent precipitations in winter and less rainfall in the vegetation period (Detekcja..., 2003). It will not alter the supply of drinking and household water but will certainly have an effect on agriculture, forest ecosystems and natural environment. Higher temperature will increase evapotranspiration. On the other hand, increased concentrations of green house gas $\mathrm{CO}_{2}$ may decrease water demands for unit production of biomass. From the plant's perspective most important will, however, be a lack of precipitation in summer which means the need of increasing the area of irrigated crops to produce food and undertaking actions to protect water related ecosystems.

\section{THE PRINCIPLE OF WATER MANAGEMENT}

As already mentioned, water resource is meant as the volume of precipitation distributed mainly in rural and forest areas (over $90 \%$ of the country's surface area). Water management deals mainly with balancing and distribution of surface (blue) waters. It seems that in the near future more attention should be paid to the possibility of managing green water resources (evapotranspiration control).

In view of plant demands one may say of ,productive” and ,unproductive” use of green waters. Basic distribution of green waters in a catchment takes place through:

- evaporation from the water table;

- evapotranspiration from natural areas (protected areas, wetlands, buffer zones, barren lands, weeds);

- evapotranspiration of crop plants and forests:

- evaporation from plant surfaces (water from interception),

- evaporation from the soil surface,

- transpiration (water used by plants for biomass production),

- irreversible intake for economic needs including household water.

"Productive" water use includes transpiration since water is indispensable for biomass production. Limiting transpiration in a given plant variety is tantamount to the decrease of yield. However, evaporation from soil or plant surfaces may be re- 
stricted without biomass losses. Evapotranspiration (green water) control consists in such intentional management of the river catchment and agricultural land use which would restrict "unproductive" water losses. It has been emphasized that many agro-technical recommendations already take account of the necessity of restricting evaporation from soil surfaces. New water-saving plant varieties are also being introduced.

It should be mentioned that, despite small volumes of irreversible water losses in relation to evapotranspiration, appropriate management of the former is necessary. The advisability of saving surface and ground waters results from the following premises:

- the necessity of maintaining natural water regime in running waters (including spring floods in river valleys) to protect natural values of river valleys;

- the need of protecting water quality since the discharge of sewage (even if treated) may pose a risk to aquatic ecosystems;

- retaining minimum flow in rivers to meet the demands of natural flora and fauna and to keep hydrologic flows;

- maintaining high water tables in rivers to provide appropriate moisture in river valleys (in water related ecosystems);

- economic determinants, increased water intake requires construction of large water and sewage treatment plants;

- periodical and local water deficits in areas of smaller water resources.

\section{SUMMARY}

Precipitation is the only source of fresh water available to natural environment and economic purposes. The evapotranspiration of natural and agricultural plants is the main water loss in the catchment balance.

Deficits of water used for economic purposes (including drinking water) are not of structural character and usually result from shortage of financial means for water acquisition. There are justified fears that global water deficits may become an important problem in fulfilling human nutritional demands. Competition for the access to water is more and more clearly visible. At present time especially in the developing countries. This is particularly true for water distribution between agriculture and natural environment. Solution to this problem is in biological progress in agriculture and in extending knowledge of water cycling in nature. It should be expected that scientific development will enable obtaining higher yields at lower water consumption. Instead of managing surface and ground waters a management strategy should be adopted in the future for the entire water resources that come from atmospheric precipitation (green and blue waters) with particular reference to evapotranspiration control. 
Research studies and analyses are needed to prepare methods for complex management of entire water resources and to understand many causal relationships. The most important problems that need to be recognised are:

- possibility of using non-technical methods to increase retention capacity of the catchment and to mitigate the effects of droughts and floods,

- the role of biological progress in limiting unit plant demands for water,

- agro-technical potential and methods of limiting losses for evaporation and the development and implementation of water-saving irrigations,

- assessment of the effect of changing dietary habits on the use of water for food production,

- organisational, economic and natural determinants of the regionalization of agricultural production in the country and internationally,

- assessment of the effect of global climate change on water demands of plants the effect of changes in temperature, $\mathrm{CO}_{2}$ concentration and rainfall distribution,

- the effect of forests and woodlots on groundwater recharge and evapotranspiration of field crops.

Increasing population density and improvement in nutrition quality require increased agricultural production. This may cause increased water consumption in both irrigated and non-irrigated agriculture. On the other hand, much water is needed to maintain forest ecosystems and natural communities. It is necessary to understand the possibility of management of the whole water resources originating from precipitation. Recognition and then implementation of methods that would enable proper distribution of water among various users is indispensable.

\section{REFERENCES}

1. BREDEMEIER M., SCHÜLER G., 2004. Forest ecosystem structures, forest management and water retention. Ecohydrol. Hydrobiol., 4, 3.

2. BROWN L.R., 2002. Water deficits growing in many countries. Water shortage may cause food shortages: www.greatlakesdirectory.org

3. BYCZKOWSKI A., 2003. Hydrologia. (Hydrology). T. 1, 2. Warszawa, Wydaw. SGGW: 416, 356.

4. Chapagain A.K., Hoekstra A.Y., 2004. Water footprints of nations. Main Report. vol. 1. Delft, the Netherlands, UNESCO-IHE: 75.

5. Drogers P., IMMERZEel W., 2008. Managing the real water consumer: Evapotranspiration. World Bank documents.

6. Directive of the European Parliament and of the Council 2000/60/EC establishing a framework for Community action in the field of water policy. OJ L327 of 22.12.2000.

7. Falkenmark M., LANNERSTAD M., 2005. Consumptive water use to feed humanity - curing a blind spot. Hydrol. Earth Syst. Sci., 9: 15-28.

8. Gerbens-Leenes P.W., Hoekstra A.Y., van Der MeEr Th., 2009. The water footprint of energy from biomass: A quantitative assessment and consequences of an increasing share of bio-energy in energy supply. Ecol. Econ., 68: 1052-1060.

9. HoEkstRa A.Y., Chapagain A.K., 2007. Water footprints of nations: Water use by people as a function of their consumption pattern. Water Res. Man., 21: 35-48. 
10. Hoffman M., Johnsson H., Gustafson A., Grimvall A., 2000. Leaching of nitrogen in Swedish agriculture - a historical perspective. Agricult. Ecosyst. Env., 80: 277-290.

11. Human Development Report, 2006. Geneva, UNESCO.

12. Implementation of the water policy and strategy of the United Nations Environment Programme. 2008. United Nations UNEP/GC.25/9.

13. Indicator and indices for decision making in water resources management, 2009. www.environ. chemeng.ntaua.gr/WSM/Newsletter/Issue4

14. KĘDZIORA A., 2006. Kształtowanie krajobrazu rolniczego dla zachowania zrównoważonej gospodarki wodnej. (Agricultural landscape management to maintain sustainable water management). In: Zrównoważony rozwój w teorii ekonomii i praktyce. Ogólnopol. konf. nauk. Wrocław, 29-30.06 .2006 . Wrocław. www.kee.ae.wroc.pl

15. Detekcja zmian klimatu i procesów hydrologii (Detection of climate changes and hydrologic processes), 2003. Ed. Z. Kundzewicz. Warszawa, Wydaw. Sorus: 151.

16. Lallana C., Marcuello C., 2004. Water exploitation index. Indicator Fact Sheet. Copenhagen, EEA.

17. Lawrance P., Meigh J., SulliaAn C., 2002. The Water Poverty Index an international comparison. Keele University. KERP, 19.

18. Lwowicz M.J., 1979. Zasoby wodne świata. (Water resources of the world). Warszawa, PWN: 438.

19. MioduszewSKI W., 1999. Ochrona i kształtowanie zasobów wodnych w krajobrazie rolniczym. (Protection and management of water resources in agricultural landscape). Falenty, Wydaw. IMUZ: 126.

20. MiodusZEwSKi W., 2006. Woda wirtualna - woda dla produkcji żywności. (Virtual water - water for food production). Gosp. Wod., 5: 173-178.

21. Mioduszewski W., 2008. Czy Polska jest krajem ubogim w wodę? (Is Poland a country poor in water?). Gosp. Wod., 5: 186-193.

22. Narodowa Strategia Gospodarki Wodnej do 2030 roku (projekt) (National Strategy of Water Management to the year 2030 (project)), 2008. Warszawa, KZGW.

23. Ochrona środowiska (Environmental protection), 2006. Warszawa, GUS.

24. OKRUSZKo T., 2005. Kryteria hydrologiczne w ochronie mokradeł. (Hydrological criterial in wetlands protection). Treatises and Monograph. Warszawa, Wydaw. SGGW: 151.

25. Ostrowski J., ŁabęDZKi L., Kowalik W., Kanecka-GesZKe E., KaspersKa-WoŁowicz W., SmaRZYŃSKA K., TUSIŃSKI E., 2008. Atlas niedoborów wodnych roślin uprawnych i użytków zielonych w Polsce (Atlas of water deficits in crop plants and grasslands in Poland). Eds J. Ostrowski, L. Łabędzki. Falenty, Wydaw. IMUZ.

26. Pimentel D., Herman R., PeCEnZa M., 2006. Natural resources and an optimum human population. www.mnforsustain.org/pimentel.

27. Renault D., 2002. Value of virtual water in food: principles and virtues. Delft, the Netherlands, UNESCO-IHE, FAO: 22.

28. Rezolucja Parlamentu Europejskiego z dnia 9.10 .2008 w sprawie sposobu rozwiązania problemu dotyczącego niedoboru wody i susz w Unii Europejskiej (2008/2074-INI). (Resolution of the European Parliament (2008/2074-INI) on the way of solving the problem of water deficit and droughts in the European Union)

29. RiJSBERMAN F.R., 2006. Water scarcity: Fact or fiction. Agricult. Water Manag., 80, 1-3.

30. SHARma B.R., 2006. Crop water requirements and water productivity: Concepts and practices. New Delhi, India, IWMI.

31. Shiklomanov, I.A., 1993. World fresh water resources. In: Water in crisis: A guide to the world's fresh water resources. Ed. P.H. Glick. Oxford, Univ. Press: 13-24.

32. Time to adapt - climate change and the European water dimension, 2007. Berlin, Federal Min. Env., Nat. Conserv. Nuclear Safety.

33. Using the Water Poverty Index to monitor progress in water sector, 2008. Wallingford, CEH, Water Policy Manag. 


\section{STRESZCZENIE}

\section{Woda dla rolnictwa i środowiska przyrodniczego}

Słowa kluczowe: gospodarka wodna, hydrologia, rolnictwo, środowisko przyrodnicze, zasoby wodne

W ostatnich latach następują dość istotne zmiany w poglądach na zadania i rolę gospodarki wodnej, w tym również na obszarach wiejskich. Podkreśla się konieczność kompleksowego gospodarowania zasobami wodnymi, uwzględniającego wszystkich użytkowników wody, w tym rolnictwa i środowiska przyrodniczego. Zwraca się uwagę, że rolnictwo i środowisko przyrodnicze, w tym lasy, są podstawowymi konsumentami wód opadowych (ewapotranspiracja), co w bilansach wodnogospodarczych nie jest uwzględniane. Coraz większe znaczenie przepisuje się wykorzystaniu wód własnych zlewni oraz stosowaniu nietechnicznych metod regulowania obiegu wody. Podkreśla się duży udział w bilansie wodnym agroekosystemów, a także ekosystemów naturalnych i zbliżonych do naturalnych, jak lasy i mokradła. Wyrazem zmian podejścia do problematyki gospodarowania wodą jest m.in. Ramowa Dyrektywa Wodna (RDW) Unii Europejskiej poświęcona ochronie wód powierzchniowych i podziemnych. W Dyrektywie dużą wagę przywiązuje się do ochrony ekosystemów wodnych i bezpośrednio zależnych od wody. Coraz częściej zwraca się uwagę, że całkowity zasób wodny jest równy objętości opadu atmosferycznego. Gospodarka wodna powinna uwzględniać nie tylko część wód znajdującą się w geologicznych warstwach wodonośnych i korytach rzek, ale również tę część, która jest retencjonowana w profilu glebowym, na terenach mokradeł. Takie elementy bilansu wodnego, jak przestrzenny rozkład, intercepcja, infiltracja, zasilanie zbiorników wód podziemnych, pojemność retencyjna gleb, spływ powierzchniowy, ewapotranspiracja, w dużym stopniu zależą od sposobu użytkowania zlewni. Przez odpowiednie użytkowanie i zagospodarowanie zlewni, stosowanie racjonalnych metod agrotechnicznych, rozbudowę małej retencji, odtwarzanie mokradeł, hamowanie odpływu wód z systemów odwadniających itp. w istotny sposób oddziałuje się na obieg wody w zlewni.

Małe zasoby wodne Polski, zwiększające się zużycie wody, zmiany klimatu oraz wymogi ochrony środowiska przyrodniczego wymuszają wdrażanie kompleksowych metod gospodarowania całością zasobów wodnych oraz poszukiwanie bliższych naturze metod ograniczania strat gospodarczych, powodowanych nadmiarem lub niedoborem wody. Oszczędność poboru wód na cele gospodarcze, w tym na potrzeby rolnictwa, umożliwi pełniejsze zaspokojenie potrzeb środowiska przyrodniczego.

Reviewers:

Received 11.09.2009

Dr Marek Łoś

Prof. Edward Pierzgalski 